\title{
Tavern Has the Recipe for Appeal and Profitability
}

\section{Kimberly Eddleston (Northeastern University)}

\section{KEYWORDS: Finance, Family Business, Restaurants.}

The restaurant industry is among the riskiest, with sometimes perilous finances and a high failure rate. But in Bristol, Rhode Island, bustling DeWolf Tavern has mastered the art of building a loyal customer base and keeping its bottom line healthy. In this interview with EIX's Kim Eddleston, DeWolf Tavern owner Sai Viswanath talks about the importance of sincerity and understanding your guests, how restaurants must go beyond being transactional businesses and build good will in their communities, and what he's learned from the Navy about discipline. 